Article - Agriculture, Agribusiness and Biotechnology

\title{
$\beta$-Glucanase Addition in Brewing Malt Produced by Reduced Time of Germination
}

Crislane Brazil ${ }^{1}$

https://orcid.org/0000-0003-1933-2673

Débora Francielly de Oliveira ${ }^{2}$

https://orcid.org/ 0000-0003-3531-8855

Rafael Augusto Duarte ${ }^{1}$

https://orcid.org/ 0000-0002-4764-479X

Juliana Minardi Galo ${ }^{3}$

https://orcid.org/ 0000-0003-3994-8504

Luciano Lucchetta ${ }^{1}$

https://orcid.org/ 0000-0001-9764-941X

Eder da Costa dos Santos ${ }^{1}$

https://orcid.org/ 0000-0003-0130-3786

Elisabete Hiromi Hashimoto ${ }^{*}$

https://orcid.org/ 0000-0002-1368-4785

${ }^{1}$ Federal University of Technology - Parana, Department of Food Engineering, Francisco Beltrao, Parana, Brazil; 'Federal University of Rondônia, Department of Food Engeneering, Ariquemes, Rondônia, Brazil; ${ }^{3}$ Federal Institute of Education, Science and Technology of Rondônia, Department of Teaching, Ariquemes, Rondônia, Brazil; ${ }^{4}$ Federal University of Technology - Parana, Department of Bioprocess and Biotechnology, Ponta Grossa, Parana, Brazil.

Received: 2018.06.21; Accepted: 2019.07.08.

*Correspondence: elisabete@utfpr.edu.br; Tel.: +55-42-3220-4800 (EHH)

\section{HIGHLIGHTS}

- The addition of $\beta$-glucanase reduced the germination time of the malt.

- The beer produced with malt germinated with $\beta$-glucanase had good sensory acceptance.

- Concentrations of 25 and $50 \mathrm{mg} . \mathrm{kg}-1$ of $\beta$-glucans resulted in adequate $\beta$-Glucan content.

- The addition of $\beta$-glucanase to malt germination did not affect the quality of the beer. 
Abstract: The $\beta$-Glucans content has straight influence on the quality of malt and beer, mainly during the filtration step. Barley presenting high $\beta$-Glucan content demands longer germination time at malting. The application of commercial $\beta$-Glucanase is an alternative to accelerate the process and preserve the quality of malt. This work aimed to evaluate the effect of commercial $\beta$-Glucanase addition in malt produced within reduced germination time (64 h). Micro-malting was conducted with BRS-Caue and Elis barley cultivars at germination time $64 \mathrm{~h}$ and $96 \mathrm{~h}$. The $\beta$-Glucanase concentration applied were 0, 25, 50 and $100 \mathrm{mg} . \mathrm{kg}$ ${ }^{1}$. Barley, malt and wort samples were analyzed to check their physical-chemical features. Beers were produced with BRS-Caue malt and the physical-chemical and sensory attributes were analyzed. The commercial enzyme addition in BRS-Caue and Elis (64 h), at concentration 25 and $50 \mathrm{mg} \cdot \mathrm{kg}^{-1}$, resulted in wort presenting proper $\beta$-Glucan content $(\leq 178$ $\left.\mathrm{mg} \cdot \mathrm{L}^{-1}\right)$. The beer produced with malt germinated for $64 \mathrm{~h}$ and added with $50 \mathrm{mg} \cdot \mathrm{kg}^{-1}$ of $\beta$ glucanase was the one showing the largest number of physical-chemical and sensory parameters similar to the beer made with malt germinated for $96 \mathrm{~h}$ (conventional process). Commercial $\beta$-glucanase application in malt allowed accelerating the malting process without affecting the quality of the malt for beer production.

Keywords: $\beta$-glucans; germination time; commercial enzyme.

\section{INTRODUCTION}

In the world, Brazil is the third largest beer producer. In 2016, the country produced approximately 14.1 billion liters of beer [1]; therefore, the demand for raw material is high. The country produces approximately $43 \%$ of the malt needed to supply brewer industries [2]. In order to fill the lack of raw material to brewing industries, many countries replace malt and barley by rice, rye, corn, oats and sorghum [3,4,5,6,7]. Although these adjuncts present lower production cost adjuncts materials can affect the physical-chemical and sensory properties of the beer [8].

Unmalted barley stands out among the adjunct materials due to its intrinsic features, which facilitates its incorporation to brew processing in beer industries. The gelatinization temperature of barley starch is similar of malted barley starch. Another advantage is the possibility to apply the barley straw to help the filtration process [9]. Using unmalted barley or the partial malt replacement by barley, or by malted barley presenting shorter germination time has been reported $[10,11,12,13]$.

The malting process includes steeping, germination and kilning [14]. The $\beta$-Glucanases $(1 \rightarrow 3,1 \rightarrow 4 \beta$-D- Glucan, 4-Glucan hydrolase, E.C.3.2.1.73) are the main enzymes produced in the germination stage. These enzymes hydrolyze the components in the cell walls of barley grains. Thefore, the total or partial replacement of malt by unmalted barley can affect the brewing process due the insufficient action of $\beta$-Glucanases and high $\beta$ Glucan content $[9,15]$. The high $\beta$-Glucan content increases wort viscosity, which causes reduced filtration and unwanted beer turbidity $[16,17]$. Thus, one of the requests from brewers is malt with $\beta$-Glucans content lower than $178 \mathrm{mg} \cdot \mathrm{L}^{-1}$ [18].

The brewing industry has interest to improve malting process to reduce cost and energy and water consume [11]. But changes in maceration, germination or drying steps may affect 
the quality of the malt for beer production. The enzymes addition may improve the malt quality and it is already commercially available. Enzymatic preparations with microbial $\beta$ Glucanases are reported as promising to reduce the content of high molecular-weight $\beta$ Glucans in barley $[9,19]$. The present study aimed to assess the quality of brewer's malt produced within a shorter germination time and added with commercial $\beta$-Glucanase in order to reduce malt production costs and to accelerate its production for brewers.

\section{MATERIAL AND METHODS}

\section{Raw Material}

The barley BRS-Caue and Elis cultivars were grown and harvested in Guarapuava-PR, Brazil in 2013. A total mass of $50 \mathrm{~kg}$ of barley were sampled and stored at $25^{\circ} \mathrm{C}$ for two months, until experimental use. The barley moisture (EBC 3.3) and protein (EBC 3.3.2) were analyzed according to the standards methods of the European Brewery Convention (EBC) [19]. Germination power was analyzed as described by Mitteleuropäische Brautechnische Analysen Kommision (MEBAK) [20]. The $\beta$-Glucan concentration was measured according to the methods described by the American Association of Cereal Chemists (AACC) [21].

\section{Malting}

The barley samples (BRS Caue and Elis, > 2.2-mm screen) were malted following two germination time programs: $64 \mathrm{~h}$ and $96 \mathrm{~h}$. For the both programs, steeping was comprised of two cycles of $4 \mathrm{~h}$ of immersion and air rest at $20^{\circ} \mathrm{C}$ in Schmidt-Seeger ${ }^{\circledR}$ [14]. Germination lasted $64 \mathrm{~h}$ (reduced time) and $96 \mathrm{~h}$ (usual time) at $20^{\circ} \mathrm{C}$. Moisture content $(\mathrm{m} / \mathrm{m})$ of the grain was monitored and adjusted daily 46\%. The kilning program was as follows: $16 \mathrm{~h}$ and 30 $\min$ at $50^{\circ} \mathrm{C}, 1 \mathrm{~h}$ at $60^{\circ} \mathrm{C}, 1 \mathrm{~h}$ at $70^{\circ} \mathrm{C}$ and $2 \mathrm{~h}$ and $30 \mathrm{~min}$ at $80^{\circ} \mathrm{C}$.

\section{$\beta$-Glucanase addition and malt analyses}

Prior to mashing the malt germinated at $64 \mathrm{~h}$, the commercial endo-1.3(4) $\beta$-Glucanase (EC 3.2.1.6, CAS no. 62213-14-3, AB Enzymes, Darmstadt, Germany) was added. The $\beta$ Glucanase solution $(5.0 \mathrm{~mL})$ was sprinkled at the concentrations: $0,25,50$ and $100 \mathrm{mg} \cdot \mathrm{kg}^{-1}$ of malt (BRS-Caue and Elis). The malt moisture content (EBC 4.2) and friability (EBC 4.15) were analyzed according to EBC [22]. The $\beta$-Glucanase activity was analyzed using AzoBarley-Glucan essay kit (Megazyme Ltda., Irlanda) as described by McCLEARY and SHAMEER [23] at $590 \mathrm{~nm}$ (Hewlett Packard, model 8453).

\section{Mashing}

Wort was prepared (EBC 4.2) and analyzed according methods described in $\mathrm{EBC}^{23}$ : wort extract (EBC 4.5.1), pH (EBC 8.17), cooking color (EBC 4.19), $\beta$-Glucan concentration (EBC 4.16.3) and diastase power (EBC 4.12.1). Wort viscosity was measured according to MEBAK 4.1.4.4 [20]. 


\section{Pilot-scale brewing}

The beer samples were brewed from BRS-Caue malt samples germinated at 64 and $96 \mathrm{~h}$ and added of commercial $\beta$-Glucanase $\left(0,25\right.$ and $\left.50 \mathrm{mg} \cdot \mathrm{kg}^{-1}\right)$. Each milled malt samples (3 kg) were mashed with $10 \mathrm{~L}$ of drinking water (chlorine free) at $40^{\circ} \mathrm{C}, 30 \mathrm{~min}$ at $50^{\circ} \mathrm{C}$ and $20 \mathrm{~min}$ at $60^{\circ} \mathrm{C}$. Then, the temperature was increased $1^{\circ} \mathrm{C} / \mathrm{min}$ until $72^{\circ} \mathrm{C}$ and kept for one hour and $15 \mathrm{~min}$ at $76^{\circ} \mathrm{C}$. The wort was diluted with $12 \mathrm{~L}$ of hot water $\left(80^{\circ} \mathrm{C}\right)$, totaling $18 \mathrm{~L}$ per malt sample. Magnum (5 g) and Mittelfriih (10 g) hops were added. The boiled wort was then transferred to the whirlpool vessel and rested for $15 \mathrm{~min}$. The wort was cooled at $23^{\circ} \mathrm{C}$ and rehydrated yeast Saccharomyces carlsbergensis (10 g, Diamond Lager Yeast) added to brew wort. Fermentation was conducted for 12 days at $12.5^{\circ} \mathrm{C}$. To improve carbonation, natural lemon juice $(15 \mathrm{~mL}$ ) and $50 \mathrm{~g}$ of sucrose were added to the $600 \mathrm{~mL}$ green beer bottle. Maturation was performed in amber glass bottles for 7 days at $17^{\circ} \mathrm{C}$. The bottled beers were then used for further beer characterization.

\section{Beer analyses}

The beer physical-chemical analyses were performed based on standards set by Adolfo Lutz Institute [24]. Samples were decarbonated at 20 and $25^{\circ} \mathrm{C}$. The parameters measured were: alcohol content (247/IV), real extract (248/IV), pH (017/IV), total acidity (234/IV), reducing sugars (239/IV) and soluble solids (315/IV). Microbiological analyses consisted of the enumeration and identification of potential pathogens according to International Standard Organization Procedures (ISO) for the quantification of Staphylococcus aureus, mesophilics at $30^{\circ} \mathrm{C}$, total and thermotolerant coliforms, yeasts and moulds [25,26,27].

\section{Sensory evaluation}

Ethical clearance approval for this study was granted by the UNIR (Federal University of Rondonia, Brazil) Research Ethics CEP/UNIR, (717442217.1.0000.5300). Descriptive sensory analysis of the beers was developed by the trained sensory panel [28]. The descriptive terminology was also developed based on the Kelly's Repertory Grid method [29]. The description terms of attribute were: color, gloss, effervescence, body, turbidity, formation of foam, stability of foam, aroma, taste and overall assessment. Reference material for the sensory perception was applied during training. Twenty-five panelists were selected considering the ability to discriminate samples and repeatability in attribute description. Four beer samples were numbered at $10^{\circ} \mathrm{C}$ were served simultaneously in glass (40 $\mathrm{mL}$ each). Evaluators drank water to avoid cross-contamination between the beer samples. Evaluation forms were presented in horizontal $9 \mathrm{~cm}$ structural intensity scale (from 0 "less" to 9 "much").

\section{Statistical analyses}

Barley, malt, wort and beer assessments data were subjected to an analysis of variance (ANOVA) and Tukey's test for the means comparisons STATISTICA software, version 7.0 [30]. Individual performance of sensorial analysis considered 2 factors, sample and assessor [28]. 


\section{RESULTS}

Table 1 presents the results of barley quality analyses.

Table 1. BRS-Caue and Elis barley cultivar characterization

\begin{tabular}{lccccc}
\hline Cultivar & $\begin{array}{c}\text { Moisture } \\
(\%)\end{array}$ & $\begin{array}{c}\text { Germinative } \\
\text { energy (\%) }\end{array}$ & $\begin{array}{c}\text { Protein } \\
(\%)\end{array}$ & $\begin{array}{c}\boldsymbol{\beta} \text { glucan } \\
(\%)\end{array}$ & $\begin{array}{c}\text { Classification* } \\
(\%)\end{array}$ \\
\hline BRS-Caue & $11.93 \pm 0.05^{\mathrm{a}}$ & $97 \pm 0.82^{\mathrm{a}}$ & $11.20 \pm 0.08^{\mathrm{a}}$ & $3.72 \pm 0.53^{\mathrm{a}}$ & $92.27 \pm 0.33^{\mathrm{b}}$ \\
BRS-Elis & $10.47 \pm 0.05^{\mathrm{b}}$ & $98 \pm 1.70^{\mathrm{a}}$ & $10.33 \pm 0.05^{\mathrm{b}}$ & $3.37 \pm 0.36^{\mathrm{a}}$ & $93.20 \pm 0.08^{\mathrm{a}}$ \\
\hline
\end{tabular}

* $2.8+2.5 \mathrm{~mm}$. Mean values in the same column followed by different superscript letters, for barley moisture, germinative energy, protein, $\beta$-Glucan and Classification, are significantly different $(p \leq$ 0.05).

The Figure 1 show $\beta$-Glucan concentration in BRS-Caue and Elis malt cultivars germinated for $64 \mathrm{~h}$ after the application of different commercial $\beta$-Glucanase concentrations.

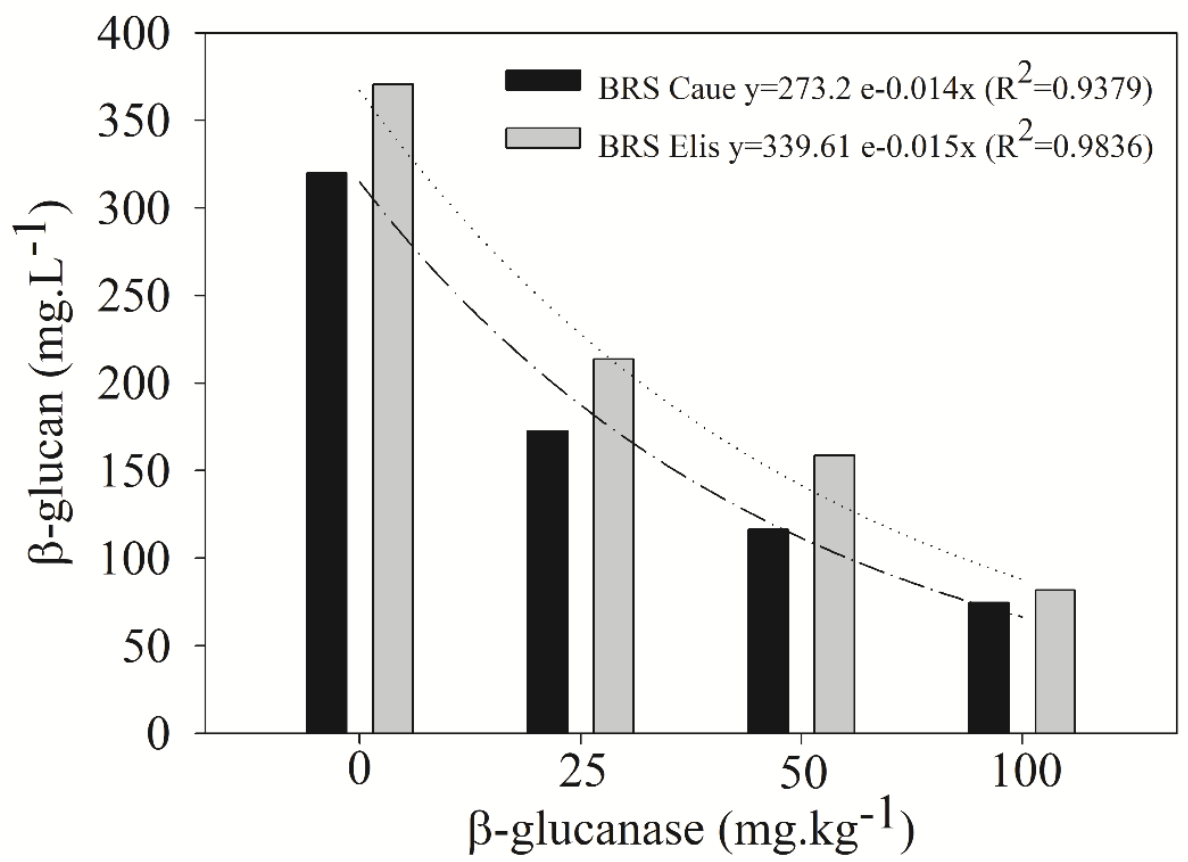

Figure 1. $\beta$-Glucan concentration in BRS-Caue and Elis malt cultivars germinated for $64 \mathrm{~h}$ after the application of different commercial $\beta$-Glucanase concentrations.

Table 2 presents the physical-chemical characteristics of malt produced from barley germinated for $96 \mathrm{~h}$ and $64 \mathrm{~h}$ added with $\beta$-glucanase at concentrations $0,25,50$ and 100 $\mathrm{mg} \cdot \mathrm{kg}^{-1}$ (BRS-Caue and Elis). 
Table 2. Physical-chemical characterization of malt produced from cultivars BRS Caue and Elis

\begin{tabular}{|c|c|c|c|c|c|}
\hline \multirow[t]{2}{*}{ Treatment } & \multicolumn{5}{|c|}{ Germination Time (h) / $\beta$-glucanase (mg. $\left.\mathrm{kg}^{-1}\right)$} \\
\hline & $96 / 0$ & $64 / 0$ & $64 / 25$ & $64 / 50$ & $64 / 100$ \\
\hline & \multicolumn{5}{|c|}{ Moisture (\%) } \\
\hline BRS Caue & $4.17 \pm 0.05^{d}$ & $4.80 \pm 0.00^{c}$ & $5.47 \pm 0.05^{\mathrm{a}}$ & $5.23 \pm 0.05^{b}$ & $5.20 \pm 0.00^{b}$ \\
\hline \multirow[t]{2}{*}{ BRS Elis } & $4.23 \pm 0.05^{d}$ & $4.73 \pm 0.05^{c}$ & $5.27 \pm 0.00^{\mathrm{a}}$ & $5.47 \pm 0.05^{\mathrm{a}}$ & $5.13 \pm 0.05^{\mathrm{a}}$ \\
\hline & \multicolumn{5}{|c|}{ Friability (\%) } \\
\hline BRS Caue & $85.0 \pm 0.86^{a}$ & $70.80 \pm 0.73^{b}$ & $68.6 \pm 0.83^{b}$ & $69.96 \pm 0.94^{b}$ & $68.70 \pm 1.36^{b}$ \\
\hline \multirow[t]{2}{*}{ BRS Elis } & $87.9 \pm 0.57^{\underline{a}}$ & $73.30 \pm 0.57^{b}$ & $71.1 \pm 0.59^{c}$ & $71.87 \pm 0.54^{\mathrm{bc}}$ & $71.63 \pm 0.37^{b c}$ \\
\hline & \multicolumn{5}{|c|}{$\beta$-Glucanase $\left(\mathrm{U}^{\mathrm{kg}}{ }^{-1}\right)$} \\
\hline BRS Caue & $471.0 \pm 22.5^{a}$ & $317.7 \pm 27.4^{c}$ & $339.3 \pm 13.3^{b c}$ & $342.7 \pm 6.60^{\mathrm{bc}}$ & $396.3 \pm 19.1^{b}$ \\
\hline BRS Elis & $462.3 \pm 10.6^{a}$ & $332.3 \pm 16.8^{b}$ & $344.3 \pm 29.3^{b}$ & $350.0 \pm 12.0^{b}$ & $380.7 \pm 17.6^{b}$ \\
\hline
\end{tabular}

Mean values in the same column followed by different superscript letters, for malt moisture, friability and $\beta$-Glucanase, are significantly different $(p \leq 0.05)$.

Table 3 presents the analyses of wort produced from malt germinated for $96 \mathrm{~h}$ and $64 \mathrm{~h}$ added with $\beta$-Glucanase at concentrations $0,25,50$ and $100 \mathrm{mg}^{-\mathrm{kg}^{-1}}$ (BRS-Caue and Elis cultivars).

Table 3. Physical-chemical characterization of wort produced from cultivars BRS Caue and Elis

\begin{tabular}{|c|c|c|c|c|c|}
\hline \multirow[t]{2}{*}{ Treatment } & \multicolumn{5}{|c|}{ Germination Time (h) / $\beta$-glucanase $\left(\mathrm{mg} \mathrm{kg}^{-1}\right)$} \\
\hline & $96 / 0$ & $64 / 0$ & $64 / 25$ & $64 / 50$ & $64 / 100$ \\
\hline & \multicolumn{5}{|c|}{ Color (EBC) } \\
\hline BRS Caue & $6.13 \pm 0.12^{\mathrm{a}}$ & $5.60 \pm 0.08^{b . c}$ & $5.50 \pm 0.00^{c}$ & $5.90 \pm 0.14^{\mathrm{ab}}$ & $5.57 \pm 0.05^{c}$ \\
\hline \multirow[t]{2}{*}{ BRS Elis } & $6.20 \pm 0.14^{\mathrm{a}}$ & $5.67 \pm 0.05^{\mathrm{b}}$ & $5.87 \pm 0.12^{b}$ & $5.70 \pm 0.00^{\mathrm{b}}$ & $5.67 \pm 0.05^{b}$ \\
\hline & \multicolumn{5}{|c|}{ Extract (\%) } \\
\hline BRS Caue & $80.90 \pm 0.08^{c}$ & $81.40 \pm 0.08^{b}$ & $81.40 \pm 0.08^{b}$ & $82.13 \pm 0.21^{\mathrm{a}}$ & $81.53 \pm 0.05^{b}$ \\
\hline \multirow[t]{2}{*}{ BRS Elis } & $81.63 \pm 0.05^{\mathrm{b}}$ & $82.10 \pm 0.16^{\mathrm{a}}$ & $82.27 \pm 0.05^{\mathrm{a}}$ & $82.23 \pm 0.05^{\mathrm{a}}$ & $82.47 \pm 0.19^{a}$ \\
\hline & \multicolumn{5}{|c|}{$\mathrm{pH}$} \\
\hline BRS Caue & $5.97 \pm 0.02^{\mathrm{a}}$ & $5.84 \pm 0.01^{c}$ & $5.94 \pm 0.01^{\mathrm{ab}}$ & $5.93 \pm 0.01^{\mathrm{ab}}$ & $5.91 \pm 0.03^{b}$ \\
\hline \multirow[t]{2}{*}{ BRS Elis } & $5.83 \pm 0.02^{\mathrm{e}}$ & $5.87 \pm 0.00^{d}$ & $5.93 \pm 0.01^{c}$ & $6.04 \pm 0.00^{\mathrm{a}}$ & $5.99 \pm 0.01^{b}$ \\
\hline & \multicolumn{5}{|c|}{ Diastatic power ( $\left.{ }^{\circ} \mathrm{WK}\right)$} \\
\hline BRS Caue & $304.3 \pm 3.86^{\mathrm{a}}$ & $277.7 \pm 6.13^{\mathrm{bc}}$ & $282.3 \pm 6.13^{b c}$ & $268.7 \pm 2.87^{c}$ & $286.0 \pm 5.89^{b}$ \\
\hline \multirow[t]{2}{*}{ BRS Elis } & $281.0 \pm 0.82^{\mathrm{a}}$ & $229.7 \pm 2.87^{b}$ & $236.3 \pm 1.89^{\mathrm{b}}$ & $242.7 \pm 18.37^{b}$ & $252.0 \pm 5,89^{b}$ \\
\hline & \multicolumn{5}{|c|}{ Viscosity (mPa.s) } \\
\hline BRS Caue & $1.45 \pm 0.01^{c}$ & $1.57 \pm 0.01^{\mathrm{a}}$ & $1.55 \pm 0.00^{\mathrm{a}}$ & $1.51 \pm 0.00^{b}$ & $1.52 \pm 0.00^{b}$ \\
\hline BRS Elis & $1.47 \pm 0.01^{d}$ & $1.59 \pm 0.00^{\mathrm{a}}$ & $1.55 \pm 0.00^{\mathrm{b}}$ & $1.52 \pm 0.00^{c}$ & $1.51 \pm 0.00^{c}$ \\
\hline
\end{tabular}


Table 4 show the physical-chemical characteristics of beer produced from malt (BRSCaue) germinated for $64 \mathrm{~h}$ and $96 \mathrm{~h}$ added with 0,25 and $50 \mathrm{mg}^{\mathrm{kg}}{ }^{-1}$ of commercial $\beta$ Glucanase.

Table 4. Physical-chemical features of beer produced with BRS-Caue malt germinated for 96 and 64 $\mathrm{h}$ and added with commercial $\beta$-Glucanase

\begin{tabular}{|c|c|c|c|c|}
\hline \multirow{2}{*}{$\begin{array}{l}\text { Treatment } \\
\text { Analyses }\end{array}$} & \multicolumn{4}{|c|}{ Germination Time (h) / $\beta$-glucanase $\left(\mathrm{mg} \mathrm{kg}^{-1}\right)$} \\
\hline & $96 / 0$ & $64 / 0$ & $64 / 25$ & $64 / 50$ \\
\hline acidity $(\% \mathrm{~m} / \mathrm{v})$ & $0.18 \pm 0.01^{c}$ & $0.17 \pm 0.01^{d}$ & $0.25 \pm 0.01^{\mathrm{a}}$ & $0.24 \pm 0.01^{b}$ \\
\hline $\mathrm{pH}$ & $4.26 \pm 0.03^{c}$ & $4.35 \pm 0.02^{b}$ & $4.48 \pm 0.05^{\mathrm{a}}$ & $4.51 \pm 0.05^{\mathrm{a}}$ \\
\hline SS* (Brix) & $7.00 \pm 0.51^{\mathrm{bc}}$ & $7.05 \pm 0.20^{b}$ & $8.40 \pm 0.11^{\mathrm{a}}$ & $6.48 \pm 0.52^{c}$ \\
\hline Alcohol (\%) & $5.15 \pm 0.1^{b}$ & $4.32 \pm 0.1^{c}$ & $6.87 \pm 0.1^{\mathrm{a}}$ & $5.12 \pm 0.1^{\mathrm{b}}$ \\
\hline Reducing sugar $\left(\mathrm{g} \cdot \mathrm{L}^{-1}\right)$ & $1.51 \pm 0,01^{c}$ & $1.28 \pm 0,02^{d}$ & $2.92 \pm 0,03^{a}$ & $2.51 \pm 0,02^{b}$ \\
\hline Real Extract (\%) & $5.01 \pm 0,16^{\mathrm{bc}}$ & $5.17 \pm 0,16^{\mathrm{ab}}$ & $5.27 \pm 0,12^{\mathrm{a}}$ & $4.97 \pm 0,08^{c}$ \\
\hline
\end{tabular}

*SS: soluble solids. Mean values in the same line followed by different superscript letters, for beer acidity, $\mathrm{pH}$, soluble solids, alcohol content, sugar, real extract, are significantly different $(p \leq 0.05)$.

Tables 5 and 6 presents the analyses of variance of the sensory analyses and resulted of the sensory analysis of the developed beers and its comparison with the conventional formulation, respectively.

Table 5. Variance analyses of judges' individual performance in the beer sensory analyses

\begin{tabular}{lcccccc}
\hline Efect & Test & Valor & F & Efect df & Error df & p \\
\hline Assessor & Wilks & 0.186728 & 1.1500 & 30 & 339.0914 & 0.167657 \\
Sample & Wilks & 0.029056 & 13.781 & 230 & 576.5266 & 0.000000 \\
\hline
\end{tabular}

Table 6. Sensory analysis of the developed beers and its comparison with the conventional formulation

\begin{tabular}{lllll}
\hline Sensorial & \multicolumn{4}{c}{ Beer samples } \\
attributes & $\mathbf{9 6 / 0}$ & $\mathbf{6 4 / 0}$ & $\mathbf{6 4} / \mathbf{2 5}$ & $\mathbf{6 4} / \mathbf{5 0}$ \\
\hline Body & $7.17^{\mathrm{a}}$ & $5.93^{\mathrm{b}}$ & $5.73^{\mathrm{b}}$ & $6.92^{\mathrm{a}}$ \\
Turbidity & $0.87^{\mathrm{a}}$ & $1.43^{\mathrm{b}}$ & $1.44^{\mathrm{b}}$ & $0.94^{\mathrm{a}}$ \\
Foam formation & $7.71^{\mathrm{a}}$ & $5.95^{\mathrm{b}}$ & $6.09^{\mathrm{b}}$ & $7.63^{\mathrm{a}}$ \\
Foam stability & $7.84^{\mathrm{a}}$ & $5.23^{\mathrm{b}}$ & $5.34^{\mathrm{b}}$ & $7.74^{\mathrm{a}}$ \\
Aroma & $7.52^{\mathrm{a}}$ & $5.80^{\mathrm{b}}$ & $6.59^{\mathrm{b}}$ & $4.43^{\mathrm{c}}$ \\
Taste & $6.94^{\mathrm{a}}$ & $4.20^{\mathrm{b}}$ & $2.67^{\mathrm{c}}$ & $7.33^{\mathrm{a}}$ \\
Color & $5.92^{\mathrm{a}}$ & $5.92^{\mathrm{a}}$ & $5.78^{\mathrm{a}}$ & $5.92^{\mathrm{a}}$ \\
Gloss & $5.78^{\mathrm{a}}$ & $6.13^{\mathrm{a}}$ & $5.62^{\mathrm{a}}$ & $6.16^{\mathrm{a}}$ \\
Effervescence & $7.76^{\mathrm{a}}$ & $7.72^{\mathrm{a}}$ & $7.80^{\mathrm{a}}$ & $8.04^{\mathrm{a}}$ \\
Overall avaliation & $8.52^{\mathrm{a}}$ & $8.26^{\mathrm{a}}$ & $8.07^{\mathrm{a}}$ & $8.47^{\mathrm{a}}$ \\
\hline
\end{tabular}

Means followed by different letters on the same line differ statistically by the Tukey test at a $95 \%$ confidence level $(p \leq 0.05)$. 


\section{DISCUSSION}

The BRS Caue and Elis cultivar presented good quality for the malt processing. The protein content was lower than $12 \%$, moisture was lower than $13 \%$ and germination power was higher than $95 \%[31,32]$. The barley grains naturally presented about 3 to $11 \%$ of $\beta$ Glucans [33]. Environmental and genetic factors affect the final $\beta$-Glucan content in barley [34]. The analyses of ten Brazilian barley cultivars (IAC) showed $\beta$-Glucan content ranged between 2.04 to $9.68 \%$ [35]. For malt production, the appropriate $\beta$-Glucan content must be 3.0 - 4.5\% [36]. The BRS Caue and Elis cultivars (2013 crop) are the results of genetic improvement [37]. And these cultivars presented $\beta$-Glucan content between $3.72 \%$ and $3.37 \%$, respectively, as shown in Table 1 .

The $\beta$-Glucan concentration $\leq 178 \mathrm{mg} \cdot \mathrm{L}^{-1}$ is the recommended maximum limit for brewing malt [38]. The BRS-Caue and Elis cultivars germinated for $64 \mathrm{~h}$ without enzyme addition presented high $\beta$-Glucan concentrations in wort $(320.0$ and $370.7 \mathrm{mg} / \mathrm{L}$, respectively). On the other hand, the addition of $100 \mathrm{mg} \cdot \mathrm{kg}^{-1}$ of commercial $\beta$-Glucanase reduced by $76.67 \%$ and $77.96 \%$ the $\beta$-Glucan content $\left(74.67\right.$ and $\left.81.67 \mathrm{mg}^{-L^{-1}}\right)$ in BRSCaue and Elis, respectively. These values at $64 \mathrm{~h}$ did not differ statistically ( $p>0.05)$ from the values detected for cultivars germinated for $96 \mathrm{~h}$.

The concentration of commercial $\beta$-Glucanase necessary to reach $178 \mathrm{mg} \cdot \mathrm{L}^{-1}$, was calculated based on the equations Figure 1 . The addition of $31.39 \mathrm{mg} \cdot \mathrm{kg}^{-1}$ in the Caue $\left(\mathrm{R}^{2}=\right.$ $0.9836)$ malt cultivar, and of $44.13 \mathrm{mg} \cdot \mathrm{kg}^{-1}$ in the BRS-Elis $\left(R^{2}=0.9379\right)$ would be enough to conduct to acceptable brewing process.

In a malting program of $120 \mathrm{~h}$ with germination temperature at $22^{\circ} \mathrm{C}\left(1^{\text {st }}\right.$ day $)$ to $17^{\circ} \mathrm{C}$ ( $2^{\text {nd }}$ day), Brazilian barley cultivars N721 and N740 presented $\beta$-Glucan content of 112 and $214 \mathrm{mg} \cdot \mathrm{L}^{-1}$, respectively [39]. Although cultivars N721 and N740 had presented high $\beta$ Glucanase activity $\left(>800.0 \mathrm{U} . \mathrm{kg}^{-1}\right)$. The $\beta$-Glucan contend presented by BRS Caue and Elis cultivars (96 h, Table 3 ) revealed higher hydrolysis of $\beta$-Glucan than N721 with $198 \mathrm{mg}^{-\mathrm{L}^{-1}}$ for $96 \mathrm{~h}$ and $112 \mathrm{mg} \cdot \mathrm{L}^{-1}$ for $120 \mathrm{~h}$ of germination [39]. Once higher temperatures in the maceration/germination stage lead to a better water absorption, the temperature may affect $\beta$-Glucan degradation [14]. Poor barley germination can affect the quality required for beer production.

The moisture content recommended for brewing malt varies from $4 \%$ to $5 \%$. The moisture content $>5 \%$ limits product storage. The aspersion of $5 \mathrm{~mL}$ of enzyme solution in malt samples $(1 \mathrm{~kg})$ increased the moisture content. All samples were dried by the same process and the enzymatic solution was applied just after drying. The moisture content ranged from $4.17 \%$ to $4.80 \%$ in the malt samples not aspersed (96/0 and 64/0) and from 5.13 to $5.47 \%$ in samples which the commercial $\beta$-Glucanase was aspersed (Table 2). All the analyses were performed up to 3 days after processing to avoid deterioration due to moisture during storage.

The sample with the shortest germination time affected the grain friability. During the germination stage, the enzymatic complex is activated and hydrolyses the grain cell wall, increasing grain friability [39]. The acceptable malt friability must be higher than $85 \%[40,41]$. Both cultivars germinated for $96 \mathrm{~h}$ reached adequate friability degree. But the same was not 
observed in samples germinated for $64 \mathrm{~h}$, that shown friability of $68.6 \%$ to $73.30 \%$, as shown in Table 2.

Genetic and environmental factors such as soil, weather, temperature and growing region can affect the enzymatic complex expression and consequently, the enzymatic activity. The analyses of eighteen barley genotypes used in the Brazilian beer industry showed variation of $\beta$-Glucanase activity from 187.02 to $518.40{\mathrm{U} . \mathrm{kg}^{-1}}^{-1}$ [42]. The BRS Caue and Elis cultivars (crop 2013), were developed through genetic improvement. These cultivars presented $\beta$-Glucanase activity of $332.3 \mathrm{U} . \mathrm{kg}^{-1}$ (BRS Elisa 64/0) and $471.0 \mathrm{U} . \mathrm{kg}^{-1}$ (BRS - Caue 96/0). The lowest $\beta$-glucanase activity $(p<0.05)$ was detected in the BRS Caue sample germinated for $64 \mathrm{~h}$ without enzyme addition. Although the samples germinated for $96 \mathrm{~h}$ showed wort with better $\beta$-Glucanase activity $(\mathrm{p}<0.05)$ than samples germinated for $64 \mathrm{~h}$ and added with the commercial enzyme (25 to $100 \mathrm{mg} \cdot \mathrm{kg}^{-1}$ ), the last one required shorter germination time (Table 2).

Germination time is important for the endogen $\beta$-glucanase expression in the grain. The $\beta$-Glucan concentration decrease was correlated to the concentration $\beta$-Glucanase added in the malt (Figure 1). Samples germinated for $64 \mathrm{~h}$ did not show significant differences $(p>0.05)$ in $\beta$-glucanase activity between different added enzymes concentration (25, 50 or $\left.100 \mathrm{mg} \cdot \mathrm{kg}^{-1}\right)$. This difference is due the differences in the analyses. $\beta$-Glucanase activity was analyzed direct in the malt using the azo barley $\beta$-Glucan method [22], which do not require a mashing step. The mashing step during $\beta$-Glucans analyses [23] allowed enzymes to be activated, including added $\beta$-Glucanase, resulting in lower $\beta$-Glucans content.

The endogenous and exogenous enzymes (commercial) during mashing led to a decrease in $\beta$-Glucan and viscosity parameters.

Germination time is important to reducing sugars content as well as Maillard reaction substrates, and beer color. The longest germination time $(96 \mathrm{~h})$ led to higher wort cooking color values (6.13 and 6.20 EBC) when compared to samples germinated for $64 \mathrm{~h}$ (5.60 and $5.67 \mathrm{EBC}$ ) in both cultivars (Table 3). It is already known that the wort cooking color directly affects the beer color [43].

The values of extract or the fine milling extract (FME) are very important during selection of a malt cultivar, values $>80.0 \%$ are recommended for brewing malt [44]. Extract consumption by the embryo is demanding for grain transformation into a new plant. Germination time $64 \mathrm{~h}$ was enough to get FME values adequate for BRS-Caue and Elis, as shown in Table 3.

The diastatic power expresses the amount of produced enzyme and the activity during malting. These enzymes are crucial for reducing sugar production, which are essential for yeast energetic metabolism in beer production. Wort presenting diastatic power higher than $200{ }^{\circ} \mathrm{WK}$ is considered suitable for brewing [45]. All wort samples presented diastatic power values $>200^{\circ} \mathrm{WK}$. Samples germinated for $96 \mathrm{~h}$ showed higher diastatic power (281.0 and $\left.304.3^{\circ} \mathrm{WK}\right)(\mathrm{p}<0.05)$, than $64 \mathrm{~h}$ germinated samples $\left(229.7\right.$ and $\left.286.0^{\circ} \mathrm{WK}\right)$ for both cultivars (Table 3).

The wort $\mathrm{pH}$ value ranged from 5.83 to 6.04 for BRS-Caue and Elis, respectively. These values are close to those recommended for brewer's malt - from 5.9 to 6.0 [41]. These $\mathrm{pH}$ 
values were adequate for the commercial $\beta$-Glucanase activity, the supplier recommended a pH range between of 4.0 to 7.0 (AB-Enzyme).

The viscosity of the wort depends on the $\beta$-Glucan content $[46,10]$. High viscosity affects the rheological properties of wort and can cause high turbidity and filtration issues during brewing $[47,10]$. Samples germinated for $96 \mathrm{~h}$ and $64 \mathrm{~h}$ added with the commercial enzyme showed viscosity values classified from very good ( $\leq 1.53 \mathrm{mPa} . \mathrm{s})$ to good (1.53 to 1.57 $\mathrm{mPa} . \mathrm{s})$. The samples germinated for $96 \mathrm{~h}$ resulted in wort with better viscosity $\leq 1.47 \mathrm{mPa} . \mathrm{s}$ (Table 3). On the other hand, samples germinated for $64 \mathrm{~h}$ without enzyme addition (64/0) presented viscosity classified just as satisfactory (1.58 to $1.61 \mathrm{mPa} . \mathrm{s})[46,10]$.

Some studies investigated de production of beer directly from barley, without malting process $[48,49,50]$. Although the possibility of producing beer with a mixture containing up to $50 \%$ malt and barley was already studied [13], however the consumer acceptability of beer produced with unmalted barley is uncertain. These studies are from 1970s - 1980s. Currently, the chance of getting a good product using raw barley would be greater, considering the genetic improvement of barley.

Goode et al [9] evaluated a $\beta$-Glucanase of Bacillus subtilis (Bioglucanase B10L) in unmalted barley. This commercial $\beta$-Glucanase reduced the $\beta$-Glucan content and showed little impact on mash filtration. Concentrations from 0.5 to 20.0 BG U.g-1 reduced wort viscosity from $1.80 \mathrm{mPa}$.s, to 1.79 to $1.74 \mathrm{mPa}$.s of unmalted barley. The wort color ranged from 5.16 to $5.49 \mathrm{EBC}$ and the extract, from $79.3 \%$ to $80.5 \%$ in unmalted barley added with 20.0 BG U.g-1 of Bioglucanase B10L [9]. The barley cultivar (Optic, Irish, harvest 2001) used by these authors presented $\beta$-glucan content (2.84\%) lower than that in BRS-Caue and Elis, whose barley presented $3.72 \%$ and $3.37 \%$ of $\beta$-Glucans before malting (Table 1 ).

The enzymatic formulation OndeaPro ${ }^{\circledR}$ (Novozymes), composed of $\alpha$-amylase, $\beta$ glucanase, xylanase, proteinase, pullulase and lipase was applied in raw barley [10]. They observed a high wort viscosity (2.09 mPa.s). Although the beer presented a good-foam low FAN concentration and diacetyl effect was observed using this formulation. In the raw barley, a concentration of $500 \mathrm{mg} \cdot \mathrm{kg}^{-1}$ of OndeaPro® was required to obtain beer with organoleptic quality similar to beer produced with malted barley [10]. In our work, the partial malting (64 h germination) of BRS-Caue and Elis required $\beta$-Glucanase concentrations approximately 10 to 20 times lower the applied by these authors. Malting stage elimination reduces process costs and quickly fulfills the demand for raw material in the brewing industry. But, cost evaluations show that the adjunct prices, as enzyme addition, must be considered.

Muller \& Methner [11], compared the conventional malting process [51] and the process under different maceration conditions at germination time 73-74 h. This modification in the process allowed more energy eficiency and better malting yield. Significant cost savings of $€ 1.27$ to 4.87 Euros per malt ton were obtained when compared to the conventional method [11]. In our work the germination time was reduced from 96 to $64 \mathrm{~h}$. Even though use of commercial $\beta$-Glucanase represents an additional cost, the difference of $32 \mathrm{~h}$ in the process must offset the expenses, since it was possible to produce a good quality malt to meet the high demand of the brewing industry.

Beer produced using malt germinated for $64 \mathrm{~h}$ and added of $50 \mathrm{mg} \cdot \mathrm{kg}^{-1}$ commercial $\beta$ Glucanase (64/50, Table 4) was that presented most similar to the conventional sample 
$96 / 00$ ( $p>0.05$ ). These two samples did not differ in alcohol, soluble solids and real extract content. The acceptable value of beer $\mathrm{pH}$ is about 4.3 to 4.6 [10]. The $\mathrm{pH}$ of the beer samples ranged from $4.26(96 / 00)$ to $4.51(64 / 50)$ (Table 4). Beer elaborated with $100 \%$ raw barley added with the enzyme OndeaPro® resulted in higher $\mathrm{pH}$ values from 4.7 to 4.72 [10]. The malt germination is an important step to produce beer with appropriate $\mathrm{pH}$ values.

The highest ethanol production (6.87\%) was observed in the sample whose soluble solids (SS) content was higher (64/25, Table 4). The content of SS of the samples ranged from $6.48^{\circ}$ Brix $(64 / 50)$ to 8.40 . (64/25). The high SS is a result of a syrup of sucrose and lemon juice addition. The syrup is added to improve the carbonation process [52]. The added sucrose was fermented and resulted in the high ethanol production found in the sample (64/25, Table 4).

All beer samples $(96 / 00,64 / 00,64 / 25$ and 64/50) presented microbiological counting lower that $1 \mathrm{Log}$ UFC. $\mathrm{mL}^{-1}$ in mesophilic, Staphylococcus aureus, molds and yeasts, total and thermotolerant coliforms. Thus, the craft beer samples presented proper microbiological quality for consumption [53]. Then, the beer samples were evaluated by sensory analyses in order to verify consumers' perception about the tested formulations.

The individual performance evaluation considered two factors (sample and taster), and $p=0.1676$ value $(p>0.05)$. This confirms the reproducibility and repeatability between the final scores of panelists, according to the results of the variance of the sensorial analyzes shown in Table 5.

The BRS-Caue wort presented viscosity ranged from 1.45 to $1.57 \mathrm{mPa}$.s (Table 3). These parameter have direct influence on turbidity. The highest turbidity was visually detected by tasters in the sample germinated for $64 \mathrm{~h}$ and $50 \mathrm{mg}^{\mathrm{kg}}{ }^{-1}$ of enzyme (Table 6).

Beer foam is one of the most important sensory quality parameters, since it requires good formation, texture, stability and adherence to the glass [54]. Foam stability is related to higher $\beta$-Glucan and coagulable nitrogen content in beer [10]. The best scores for formation and stability were observed in the $96 / 00$ and $64 / 50$ beer formulations. The scores on these two samples were very close, except for the aroma, the 64/50 was the less aromatic. However, the aroma did not negatively affect the overall evaluation of the $64 / 00$ formulation, since there was no sensorial difference for this attribute among all the different samples analyzed.

A concentration of $31.39 \mathrm{mg} . \mathrm{kg}^{-1}$ of commercial $\beta$-Glucanase would be enough to reach $\beta$-Glucan content $=178 \mathrm{mg} \cdot \mathrm{L}^{-1}$ (Figure 1 ). But the statistical treatment of the sensorial results showed that the addition of a higher concentration of $\beta$-Glucanase $\left(50 \mathrm{mg} \cdot \mathrm{kg}^{-1}\right)$ and the reduction of the germination time from 96 to 64 hours did not negatively interfere in the sensorial characteristics of the beer, ensuring a good consumer acceptance. On the other hand, beer produced with malt germinated for $64 \mathrm{~h}$ without enzyme addition presented moderate color, gloss and body, low aroma content, foam formation and stability, and poor taste. Thus, according to Garcia-Villalba et al [55] and Fumi et al [56] this formulation did not present sensorial characteristics expected for a beer, since for these authors beer taste must be suitable for the type of beer and is characterized by aroma and palatefulness, the sparkle and the bitter taste.

\section{CONCLUSION}


In this work we showed that an acceleration of malting process is possible, reducing germination time to $64 \mathrm{~h}$ and adding $\beta$-Glucanase. Previous characterization of barley cultivars is important to preview the concentration necessary of commercial enzyme to achieve the quality demanded by the brewers. But the analysis of the final product determines adjusts in the $\beta$-Glucanase necessary to produce beer with good acceptance by the consumer. Considering the cultivars currently used commercially in Brazil, the 50 mg. $\mathrm{kg}^{-1}$ is enough to produce a good quality malt, reducing germination time from $96 \mathrm{~h}$ to 64 $\mathrm{h}$. The reduction of $32 \mathrm{~h}$ in the process of germination of the brewing malt shown in this work represents an increase in the production capacity, considering the high malt demands of the breweries in the country.

Conflicts of Interest: "The authors declare no conflict of interest."

\section{REFERENCES}

1. Brasil. Ministério da Agricultura, Pecuária e Abastecimento. Brasil é o terceiro no ranking mundial de produção de cerveja [Internet]. [Brasília]: Portal do Brasil; 2017 [cited 2017 Aug 28]. Available from: http://www.brasil.gov.br/economia-e-emprego/2017/08/brasil-e-o-terceiro-noranking-de-producao-mundial-de-cerveja.

2. Vasconcelos Y. Inovações cervejeiras. São Paulo: Pesquisa Fapesp; 2017 [cited 2017 Dec 15]; 251:19-25. Available from: Http://Revistapesquisa.Fapesp.Br/2017/01/09/InovacoesCervejeiras.

3. Kordialik-Bogacka E, Bogdan P, Diowksz A. Malted and Unmalted Oats In Brewing. J Inst Brew. 2014; 130:390-8.

4. Poreda A, Czarnik A, Zdaniewicz M, Jakubowski M, Antkiewicz P. Corn Grist Adjunct Application an influence on the brewing process and beer quality. J Inst Brew. 2014; 120:77-81.

5. Schnitzenbaumer B, Karl CA, Arendt EKA. Comparison of white nigerian and red italian sorghum (Sorghum Bicolor) as brewing adjuncts based on optimized enzyme additions. J Am Soc Brew Chem. 2013; 71:248-57.

6. Hübner F, Schehl BD, Gebruers K, Courtin M, Delcour JA, Arendt EK. Influence of germination time and temperature on the properties of rye malt and rye malt based worts. J Cereal Sci. 2010; 52:72-79.

7. Depraetere S, Delvaux F, Coghe S, Delvaux F. Wheat variety and barley malt properties: influence on haze intensity and foam stability of wheat beer. J Inst Brew. 2004; 110:200-6.

8. Bogdan P, Kordialik-Bogacka E. Alternatives do malt in brewing. Trends in Food Science \& Technology. 2017; 65:1-9.

9. Goode DL, Wijngaard HH, Arendt EK. Mashing With Unmalted Barley - impact of malted barley and commercial enzyme (Bacillus spp.) additions. Tech Q Master Brew Assoc Am. 2005; 42:184-98.

10. Steiner E, Auer A, Becker T, Gastl M. Comparison of beer quality attibutes between beers brewed with $100 \%$ barley malt and 100\% barley raw material. J Sci Food Agric. 2012; 92:80313.

11. Muller C, Methner FJ. An accelerated malting procedure- influences on malt quality and cost saving by reduced energy consumption and malting losses. J Inst Brew. 2015; 121:181-92. 
12. Cooper CM, Evans DE, Yousif A, Metz N, Koutoulis A. Comparison of the impact on the performance of small-scale mashing with different proportions of unmalted barley, Ondea Pro®, malt and rice. J Inst Brew. 2016; 122:218-27.

13. Curi RA, Venturini-Filho WG, Nojimoto T. Beer production using barley as a malt adjunct: physical-chemical, and sensory analyses. Braz J Food Technol. 2009; 12:106-12.

14. Kunze W. Tecnología para cerveceros y malteros. Berlin: Versuchs-Und Lehranstalt Für Brauerei; 2006.

15. Farzaneh V, Ghodsvali A, Bakhshabadi H, Zare Z, Carvalho IS. The impact of germination time on the some selected parameters through malting process. Int J Biol Macromol. 2017; 94:6638.

16. Wang J, Zhang G, Chen J, Wu F. The changes of $\beta$-glucan content and $\beta$-glucanase activity in barley before and after malting and their relationships to malt qualities. Food Chem. 2004; 86:223-8

17. Kuntz RJ, Bamforth CW. Time course for the development of enzymes in barley. J Inst Brew. 2007;113(2):196-205.

18. European Brewery Convention. 18th Standart malt. Analyses committee. November, 2011.

19. Hattingh M, Alexander A, Meijering I, Van Reenena CA, Dicks LMT. Malting of Barley with combinations of Lactobacillus Plantarum, Aspergillus Niger, Trichoderma Reesei, Rhizopus Oligosporus and Geotrichum Candidum to enhance malt quality. Int J Food Microbiol. 2014; 173:36-40.

20. MEBAK - Mitteleuropäische Brautechnische Analysen Kommission: raw materials: barley, adjuncts, malt, hops and hop products, collection of brewing analyses methods of the Mitteleuropäische Brautechnische Analysenkommission. MEBAK. Freising-Weihenstephan; 2011. 341p.

21. American Association of Cereal Chemists. Approved methods of AACC. 9 ed. St. Paul: American Association of Cereal Chemists; 2000.

22. European Brewery Convention - EBC. Analítica EBC. 5th ed. Zurich: Brauerei - und getränkeroudschau; 1998.

23. Mccleary BV, Shameer I. Assay of malte -glucanase using azo-barley glucan: an improved preciptant. J Inst Brew. 1987;93:87-90.

24. Instituto Adolfo Lutz. Normas analíticas. Métodos químicos e físicos para análise de alimentos. 3rd ed. São Paulo: Instituto Adolfo Lutz; 2004.

25. International Standard Organization. ISO 6888-1:1999. Microbiology of food and animal feeding stuffs - Horizontal method for the enumeration of coagulase-positive staphylococci (Staphylococcus aureus and other species). [Geneva]: International Standard Organization; 1999.

26. International Standard Organization. ISO 4833:2003. Microbiology of food and animal feeding stuffs - Horizontal method for the enumeration of microorganisms - Colony-count technique at $30^{\circ} \mathrm{C}$. [Geneva]: International Standard Organization; 2003.

27. International Standard Organization. ISO 21527-1:2008. Microbiology of food and animal feeding stuffs - Horizontal method for the enumeration of yeast and moulds - Part 2: Colony count technique in products with water activity less than or equal to 0,95. [Geneva]: International Standard Organization; 2008. 
28. International Standard Organization. ISO 8586:2012. Sensory analyses -- General guidelines for the selection, training and monitoring of selected assessors and expert sensory assessors. Geneva]: International Standard Organization; 2012.

29. Moskowitz HR. Product testing and sensory evaluation of foods. Westport: Food and Nutrition Press; 1983.

30. STATSOFT Inc. STATISTICA for Windows. Version 7.0. Tulsa; 2004.

31. BRASIL. Ministério da Agricultura, Pecuária e Abastecimento. Portaria no 691 de 22 de novembro de 1996. Diário Oficial da União. 1996 nov. 25; Seção 1, p.24751-2.

32. De Mori C, Minella E. Aspectos econômicos e conjunturais da cultura da cevada [Internet]. Passo Fundo: Embrapa Trigo. 2012; 28 p. Available from: http://www.cnpt.embrapa.rr/biblio/do/p_do139.htm.

33. Waszkiewicz-Robak B, Karwowska W, Swiderski F. Beta-glucan as a component of functional food. Bromatol Chem Toksykol. 2005; 3:301-6.

34. Anker-Nilssen K, Sahlstrøm S, Knutsen SH, Holtekjølen AK, Uhlen AK. Influence of growth temperature on content, viscosity and relative molecular weight of water-soluble b-glucans in barley (Hordeum Vulgare L.). J Cereal Sci. 2008; 48:670-7.

35. Fujita AH, Figueroa MOR. Nutrient profile and b-glucans content in cereal seeds and foodstuffs contain them. Food Sci Technol. 2003; 23:116-20.

36. Palmer GH, Shirakashi T, Sanusi LA. Physiology of germination. EBC Congress 1989. p. 63-74.

37. Minella, E. Reunião nacional de pesquisa de cevada Indicações técnicas para a produção de cevada cervejeira nas safras 2013 e 2014. Minella E, editor. Passo Fundo: Embrapa Trigo, 2013; $105 \mathrm{p}$.

38. European Brewery Convention (EBC). 18th Standard Malt. Analysis Committee. November, 2011.

39. Beletti AM, Duarte F, Kraemer-Georg JE. Temperature on the development activity of $(1-3,1,4)$ B-glucanases enzyme and degradation of B-glucanos during malting. Cienc Rural. 2012;42(3):467-73.

40. Briggs DE. Malt modification, a century of evolving views. J Inst Brew. 2002; 108:395-405.

41. MEBAK. Mitteleuropäische Brautechnische Analysen Kommission. 4th ed. Anger HM, editor. Selbstverlag Der Mitteleurop"Aischen Brautechnischen Analysen Kommission. FreisingWeihenstephan, Germany; 2002.

42. George-Kraemer JE, Caierão E, Minella E, Barbosa-Neto JF, Cavalli SS. The (1-3, 1-4) Bglucanases in malting barley: enzyme survival and genetic and environmental effects. $\mathrm{J}$ Inst Brew. 2004;110(4):303-8.

43. Spiel G. Current and future trends in barley quality requirements. 1999. [cited 2014 August 02]. Available from: Http://Www.Regional.Org.Au/Au/Abts/1999/Spiel.Htm.

44. Fox GP. Chemical composition in barley grains and malt quality. In: Zhang, Guoping, Li, Chengdao, editors. Genetics and improvement of barley malt quality. Dordrecht: Springer, Hangzhou: Zhejiang University Press; 2009; p. 63-98.

45. Kreisz S. Malting. In: Eblinger HM. Handbook of brewing: processes technology, markets. Weinheim: Wiley-Vch Verlag Gmbh \& Co. Kgaa; 2009.

46. Narziß L. Die technologie der malzbereitung, die bierbrauerei. Ferdinand Enke Verlag, Stuttgart; 1999. 
47. Kühbeck F, Back W, Krottenthaler M. Influence of lauter turbidity on wort composition, fermentation performance and beer quality in large-scale trials. J Inst Brew. 2006;112(3):22231.

48. Allen W. Barley and high adjunct brewing with enzymes. Brewers Digest. 1987; 62:18-26.

49. Klopper WJ. Barley as a raw material for brewing. Brauwelt. 1969; 109:753-7.

50. Knoepfel H, Pfenninger $\mathrm{H}$. Special aspects of enzymic processing of unmalted grain. Spezielle aspekte der enzymatic chen rohfruchtverarbeitung. Schweizer Brauerei-Rundschau 1974; 85:213-20.

51. MEBAK - Mitteleuropäische Brautechnische Analysen Kommission Brautechnische Analyse methoden, Band Rohstoffe, Selbstverlag Der Mebak. Freising-Weihenstephan, Germany; 2006.

52. Piddocke MP, Kreisz S, Heldt-Hansen HP, Nilsen KF, Olsson L. Physiological characterization of brewer's yeast in high-gravity beer fermentations with glucose or maltose syrups as adjuncts. Appl Microbiol Biotechnol. 2009; 84:453- 64.

53. Brasil. Ministério da Agricultura, Pecuária e Abastecimento. Instrução Normativa $n^{\circ} 54$, de 5 de novembro de 2001. Estabelece a identidade e qualidade dos produtos de cervejaria destinados ao consumo humano. Diário Oficial da União.2001 nov 6.

54. Evans DE, Sheehan MC. Don't be fobbed off: the substance of beer foam. J Am Soc Brew Chem. 2002;60:47-57.

55. Garcia-Villalba R, Cortacero-Ramirez S, Segura-Carretero A, Fernandez-Gutierrez A. Free-zone capillary electrophoresis analysis of Hordein patterns at different stages of barley malting. J Agric Food Chem. 2006; 54:6713-8.

56. Fumi M, Galli R, Lambri M, Donadini G, De Faveri D. Impact of fullscale brewing processes on lager beer nitrogen compounds. Eur Food Res Technol. 2009; 230:209-16.

(c) 2018 by the authors. Submitted for possible open access publication under the terms and conditions of the Creative Commons Attribution (CC BY NC) license (https://creativecommons.org/licenses/by-nc/4.0/). 